\title{
TINGKAT PENGETAHUAN PENYAKIT INFEKSI MENULAR SEKSUAL DAN KOMPLIKASINYA PADA SISWA SEKOLAH MENENGAH ATAS NEGERI JATINANGOR
}

\author{
Pati Aji Achdiat, Rasmia Rowawi, Dina Fatmasari, dan Reyshiani Johan \\ Departemen Ilmu Kesehatan Kulit dan Kelamin, Fakultas Kedokteran Universitas Padjadjaran \\ E-mail: anamorphic83@gmail.com
}

\begin{abstract}
ABSTRAK. Infeksi menular seksual (IMS) adalah infeksi yang penularannya terutama melalui hubungan seksual. World Health Organization (WHO) pada tahun 2016 menyatakan terdapat lebih dari 1 juta orang menderita IMS setiap hari. IMS memiliki pengaruh yang sangat besar pada kesehatan seksual dan reproduktif di seluruh dunia. Komplikasi dari IMS dapat menyebabkan kemandulan, gangguan kehamilan, gangguan pertumbuhan, kanker, dan memudahkan seseorang terkena infeksi human immunodeficiency diseases (HIV). Tingkat pengetahuan masyarakat diketahui berkorelasi dengan tingginya kejadian IMS di masyarakat khususnya remaja. Peningkatan pengetahuan dengan penyebaran informasi seperti kegiatan penyuluhan tentang IMS dan komplikasinya merupakan salah satu upaya penting yang harus dilakukan untuk mengurangi angka kejadian IMS di masyarakat. Kegiatan pengabdian kepada masyarakat (PPM) berupa penyuluhan ini dilakukan di SMA Negeri Jatinangor, Kecamatan Jatinangor, Kabupaten Sumedang. Peserta penyuluhan yaitu siswa dengan total peserta 50 orang. Pengumpulan data dilakukan dengan menggunakan kuesioner. Setiap lembar kuesioner terdiri dari 10 pertanyaan, yang meliputi definisi, jenis-jenis penyakit, cara penularan, tanda dan gejala, komplikasi, dan pencegahan IMS. Tingkat pengetahuan seluruh siswa SMA tentang IMS dan komplikasinya sebelum dilakukan penyuluhan masih cukup, yaitu 38,2\% pertanyaan yang dapat dijawab dengan benar oleh peserta penyuluhan. Penyuluhan dapat meningkatkan pengetahuan siswa tentang jenisjenis penyakit IMS dan komplikasinya. Siswa SMA diharapkan dapat menjadi ujung tombak dalam penyebaran informasi penyuluhan pada keluarga dan masyarakat, sehingga dapat menurunkan angka kejadian dan penularan IMS pada masyarakat.
\end{abstract}

Kata kunci: Penyuluhan; infeksi menular seksual

ABSTRACT. Sexually transmitted infections (STIs) are infections whose transmission is mainly through sexual intercourse. The World Health Organization (WHO) stated in 2016 that more than 1 million people suffer from STIs every day. STIs have a huge influence on sexual and reproductive health throughout the world. Complications from STIs can cause infertility, pregnancy disorders, growth disorders, cancer, and make it easier for someone to get infected with human immunodeficiency diseases (HIV). The level of knowledge of the community is known to correlate with the high incidence of STIs in the community, especially adolescents. Increased knowledge with the dissemination of information such as counseling activities on STIs and their complications is one of the important efforts that must be made to reduce the incidence of STIs in the community. Community service activities in the form of counseling were carried out at Jatinangor Public High School, Jatinangor District, Sumedang Regency. Extension participants are students with a total of 50 participants. Data collection is done using a questionnaire. Each questionnaire consists of 10 questions, including definitions, types of diseases, modes of transmission, signs and symptoms, complications, and prevention of STIs. The level of knowledge of all high school students about STIs and their complications before counseling is still enough, 38.2\% of questions that can be answered correctly by the participants. Counseling can increase students' knowledge about the types of STI diseases and their complications. High school students are expected to be the spearhead in disseminating information on education to families and communities, so as to reduce the incidence and transmission of STIs in the community.

Key words: counselling; sexually transmitted disease

\section{PENDAHULUAN}

Infeksi menular seksual (IMS) adalah infeksi yang penularannya terutama melalui hubungan seksual (Gutierrez, dkk., 2016). Terdapat lebih dari 30 jenis kuman berbeda yang diketahui ditularkan melalui kontak seksual. Infeksi yang paling sering ditemukan antara lain gonore, klamidiasis, trikomoniasis, herpes genitalis, infeksi human papilloma virus (HPV), hepatitis $\mathrm{B}$, dan sifilis (WHO, 2018). IMS memiliki pengaruh yang sangat besar pada kesehatan seksual dan reproduktif di seluruh dunia. Komplikasi dari IMS dapat menyebabkan kemandulan, gangguan kehamilan, gangguan pertumbuhan, kanker, dan memudahkan seseorang terkena infeksi human immunodeficiency diseases (HIV) (Hakim, 2011).

World Health Organization (WHO) pada tahun 2016 menyatakan terdapat lebih dari 1 juta orang menderita IMS setiap hari (WHO, 2018). Centres for Disease Control (CDC) pada tahun 2008 memperkirakan terdapat lebih dari
110 juta kasus IMS pada laki-laki dan perempuan di United States. Dari perkiraan CDC yaitu 20 juta kasus infeksi baru per tahun, separuh di antaranya ialah orang muda berusia 15-24 tahun (CDC, 2018). Data dari UNFPA dan WHO menyebutkan 1 dari 20 remaja tertular IMS setiap tahunnya (BKKBN, 2013). Hal ini menunjukkan masih tingginya kejadian IMS di kalangan remaja dan diduga disebabkan oleh kurangnya pengetahuan remaja tentang IMS serta sikap mereka terhadap IMS. Di Indonesia, angka prevalensi IMS bervariasi menurut daerah.

Peningkatan insidensi IMS tidak terlepas dari kaitannya dengan perilaku beresiko tinggi. Dalam IMS yang dimaksud dengan perilaku beresiko tinggi ialah perilku yang menyebabkan seseorang mempunyai resiko besar terserang penyakit. Yang tergolong kelompok resiko tinggi, yaitu usia 20-34 tahun pada laki-laki, usia 16-24 tahun pada wanita, usia 20-24 tahun pada kedua jenis kelamin, pelancong, pekerja seks komersial atau wanita tuna susila, pecandu narkotika, dan homoseksual (Hakim, 2013). 
Remaja adalah fase yang memisahkan masa kanakkanak dengan masa dewasa. Tahap ini merupakan periode transisi yang membutuhkan perhatian dan proteksi khusus. Berbagai perubahan pada masa remaja menyebabkan remaja mulai tertarik pada lawan jenis dan mempunyai rasa ingin tahu yang besar (UNCF, 2018). Peluang remaja untuk tertarik dalam hubungan seksual berkembang dalam lingkungan pergaulan sosial yang kompleks dan dinamik (Stovel, dkk., 2008). Remaja dianggap belum cukup memiliki pengetahuan yang komprehensif tentang pemeliharaan kesehatan reproduksi, Beberapa faktor penyebabnya adalah (1) minimnya pendidikan kesehatan reproduksi dan seksualitas yang komprehensif, (2) kontrol keluarga dan masyarakat yang cenderung semakin rendah, (3) semakin terbukanya akses informasi mengenai seksualitas termasuk pornografi dari media atau internet yang mempermudah remaja untuk mengakses dan memanfaatkannya secara tidak benar, (4) tingkat permisifitas (serba boleh) dari hubungan antara lakilaki dengan perempuan yang cenderung melonggar, (5) perasaan bahwa dirinya tidak mungkin terjangkit penyakit apapun, (6) kebutuhan untuk mencoba pengalaman baru, (7) nilai-nilai cinta atau hubungan lawan jenis yang cenderung disalahgunakan, (8) kurangnya pemahaman remaja akan akibat dari perilaku seks tidak aman yang dilakukannya, (9) semakin banyaknya tempat pelacuran baik yang terlokalisir ataupun tidak, (10) mitos-mitos yang berkembang di masyarakat tentang perilaku seksual dan dampaknya, (11) tidak sedikit masyarakat yang masih belum bisa menerima kehadiran pendidikan seksualitas bagi keluarga. Sehingga anak remaja cenderung untuk mencari informasi kepada teman atau media yang justru tidak mendidik (BKKBN, 2013).

Pengetahuan merupakan informasi yang diketahui atau disadari oleh seseorang. Pengetahuan muncul ketika seseorang menggunakan akal budinya untuk mengenali benda atau kejadian tertentu yang belum pernah dilihat atau dirasakan sebelumnya (Wawan dan Dewi, 2010). Faktor-faktor yang mempengaruhi tingkat pengetahuan yaitu pendidikan, pekerjaan, sosial, lingkungan, keyakinan, usia, sosial, budaya, dan ekonomi (Svensson dan Waern, 2018). Semakin tinggi tingkat pengetahuan seseorang maka semakin tinggi pula kemampuan individu tersebut di dalam melakukan penilaian terhadap suatu materi atau objek. Penilaian tersebut inilah yang akan menjadi landasan seseorang untuk bertindak (Wawan dan Dewi, 2010). Keterbatasan pengetahuan tentang penyakit IMS dapat menjadi pemicu tingginya angka kejadian dan penularan penyakit infeksi menular seksual di masyarakat. Pada beberapa negara disebutkan bahwa pelaksanaan program penyuluhan yang intensif akan menurunkan insidensi IMS atau paling tidak insidensinya relatif tetap.

Kegiatan pengabdian kepada masyarakat (PPM) ini dilakukan di Sekolah Menengah Atas (SMA) Negeri Jatinangor, Kecamatan Jatinangor, Kabupaten Sumedang. Lokasi ini dipilih karena berada di sekitar Kampus
Universitas Padjadjaran Jatinangor dan di wilayah ini belum pernah dilakukan upaya peningkatan pengetahuan mengenai IMS dan komplikasinya pada siswa sekolah. SMA Negeri Jatinangor juga merupakan satu-satunya SMA yang terdapat di wilayah Kecamatan Jatinangor, Kabupaten Sumedang, sehingga diharapkan penelitian ini dapat mewakili dan menggambarkan karakteristik para remaja yang berada di wilayah Kecamatan Jatinangor, Kabupaten Sumedang. Siswa SMA diharapkan dapat menjadi ujung tombak dalam penyebaran informasi penyuluhan pada keluarga dan masyarakat, sehingga dapat menurunkan angka kejadian dan penularan penyakit IMS di masyarakat.

Penyuluhan ini bertujuan untuk menilai tingkat pengetahuan siswa tentang IMS dan komplikasinya. Hasil penelitian ini diharapkan dapat memberikan gambaran mengenai pengetahuan masyarakat tentang penyakit IMS, serta dapat dimanfaatkan oleh instasi terkait dalam pencegahan dan pengendalian IMS.

\section{METODE}

Metode yang digunakan pada pengabdian masyarakat ini berupa penyuluhan mengenai IMS dan komplikasinya pada siswa SMA. Jumlah peserta yang hadir sebanyak 50 orang siswa. Pengumpulan data dilakukan dengan menggunakan kuesioner yang diisi sebelum dan setelah para siswa mendapatkan penyuluhan. Setiap lembar kuesioner terdiri dari 10 pertanyaan, yang meliputi definisi, jenis-jenis penyakit, cara penularan, tanda dan gejala, komplikasi, dan pencegahan IMS. Seluruh data bersifat rahasia dan hanya digunakan untuk keperluan penelitian ini.

Kuesioner penyuluhan menggunakan modifikasi kuesioner Svensson dkk. ${ }^{9}$ Kriteria penilaian rendah apabila 25\% dari kuesioner yang terjawab benar, cukup apabila 26\%-50\% dari kuesioner yang terjawab benar, baik apabila 51\%-75\% dari kuesioner yang terjawab benar, tinggi apabila $>75 \%$ dari kuesioner yang terjawab benar. Penelitian ini telah disetujui oleh Komite Etik Universitas Padjadjaran. Keikutsertaan peserta bersifat sukarela dan peserta dapat mengundurkan diri setiap saat dari penelitian ini. Setiap informasi dan data penelitian akan diperlakukan secara rahasia, sehingga tidak memungkinkan untuk diketahui orang lain. Hasil dari setiap kuesioner dihitung secara manual, tidak menggunakan statistik.

\section{HASIL DAN PEMBAHASAN}

Kegiatan PPM dilaksanakan pada hari Jumat, 26 Oktober 2018 pada pukul 09.00-11.30 di SMA Negeri Jatinangor, Kecamatan Jatinangor, Kabupaten Sumedang. Peserta penyuluhan yaitu siswa dengan total peserta 50 orang. Pengambilan data dilakukan pada saat sebelum dan sesudah penyuluhan melalui kuesioner tentang pengetahuan peserta penyuluhan terhadap IMS dan komplikasinya. 
Kegiatan penyuluhan bertempat di ruang kelas SMA Negeri Jatinangor. Penyuluhan dimulai dengan pengisian daftar hadir, pengisian kuesioner sebelum penyuluhan (Gambar 1), kemudian pembukaan oleh Kepala Sekolah dan perwakilan dosen pembimbing lapangan (DPL) (Gambar 2). Penyampaian materi dilakukan dengan ceramah, dan diskusi (Gambar 3). Kegiatan tersebut berlangsung lancar, tepat waktu, dan terlihat antusiasme dari peserta penyuluhan pada saat diskusi dan tanya jawab (Gambar 4). Penyuluhan ditutup dengan pengisian kuesioner setelah penyuluhan dan foto bersama panitia dengan peserta penyuluhan (Gambar 5 dan 6).

Dari hasil kuesioner sebelum penyuluhan (Tabel 1), diketahui bahwa tingkat pengetahuan seluruh siswa tentang IMS dan komplikasinya sudah cukup. Pemberian materi penyuluhan diketahui meningkatkan pengetahuan siswa. Dari hasil kuesioner sebelum penyuluhan diketahui bahwa $38,2 \%$ pertanyaan yang dapat dijawab dengan benar oleh peserta penyuluhan dan hanya $87,6 \%$ pertanyaan yang dapat dijawab dengan benar oleh peserta penyuluhan setelah mendapat penyuluhan.

Sekitar 58\% peserta penelitian sudah memahami definisi IMS adalah infeksi yang penularannya dapat melalui hubungan seksual dan non-seksual, seperti darah. Berdasarkan hasil penelitian ini diketahui bahwa $40 \%$ peserta sudah memahami cara penularan penyakit IMS yaitu melalui darah, jalan lahir (ibu yang menderita IMS), kontak tubuh/badan, dan kebersihan alat reproduksi yang tidak terjaga baik. Dari hasil penelitian ini diketahui hanya $46 \%$ peserta penelitian yang mengetahui tanda dan gejala infeksi menular seksual, yaitu keputihan pada wanita, kencing nanah pada pria, borok pada kelamin, dan kutil pada kelamin.

Sekitar $44 \%$ peserta mengetahui jenis-jenis IMS yang dapat disembuhkan dan $18 \%$ peserta mengetahui jenis-jenis IMS yang tidak dapat disembuhkan. Hasil penelitian Svensson dkk. (Svensson dan Waern, 2018) menunjukkan bahwa sebagian besar $(87,3 \%)$ peserta mengetahui bahwa HIV adalah penyakit infeksi menular seksual yang tidak dapat disembuhkan, sedangkan $24,5 \%$ peserta mengetahui bahwa penyakit IMS ada yang dapat disembuhkan. Penelitian lain yang dilakukan Awang dkk. (Awang, dkk., 2013) diketahui bahwa 1,3\% peserta penelitian hanya mengetahui bahwa gonore dan klamidia adalah penyakit IMS.

Sebagian kecil (30\%) peserta sudah memahami komplikasi IMS, yaitu hamil diluar kandungan, mandul, resiko tertular HIV, abortus dan lahir prematur pada wanita hamil, kanker pada bibir kemaluan wanita, kanker leher rahim pada wanita, kanker penis pada pria, resiko menularkan pada bayi untuk ibu hamil. Svensson dkk. (Svensson dan Waern, 2018) melaporkan hanya 14,7\% peserta penelitian mengetahui bahwa penyakit IMS dapat menyebabkan kemandulan. Hasil penelitian Svensson dkk. tersebuat sama dengan hasil penelitian yang dilaporkan oleh Paz-Bailey dkk. Sekitar 38\% peserta penelitian sudah mengetahui cara pencegahan penyakit IMS, yaitu dengan cara abstinance, be faithfull, condom, dan drugs.

Meningkatkan pengetahuan masyarakat tentang IMS merupakan cara yang paling tepat untuk menghentikan penularan terhadap penyakit-penyakit IMS. Peningkatan pengetahuan melalui pemberian informasi seperti penyuluhan merupakan suatu bentuk persuasi untuk memberikan fakta ilmiah dan pesan, sehingga membuka peluang terjadinya perubahan sikap dalam masyarakat (Svensson dan Waern, 2018). Hal ini dibuktikan melalui penelitian ini yaitu penyuluhan dapat meningkatkan pengetahuan masyarakat khususnya siswa SMA tentang penyakit IMS dan komplikasinya, sehingga dapat menurunkan angka kejadian dan penularan IMS dalam masyarakat.

\section{SIMPULAN}

Tingkat pengetahuan seluruh siswa SMA tentang IMS dan komplikasinya sebelum dilakukan penyuluhan sudah cukup. Pemberian materi penyuluhan diketahui meningkatkan pengetahuan siswa. Dari hasil kuesioner sebelum penyuluhan diketahui bahwa $38,2 \%$ pertanyaan yang dapat dijawab dengan benar oleh peserta penyuluhan dan terdapat peningkatan menjadi $87,6 \%$ pertanyaan yang dapat dijawab dengan benar oleh peserta penyuluhan setelah mendapat penyuluhan.

Penyebaran informasi tentang IMS dan komplikasinya merupakan salah satu upaya penting yang harus dilakukan untuk menurunkan angka kejadian dan penularan IMS dalam masyarakat. Pemahaman masyarakat yang baik tentang IMS dapat mendukung program pencegahan dan pengendalian penyakit IMS. Penyuluhan dapat meningkatkan pengetahuan siswa tentang jenis-jenis penyakit IMS dan komplikasinya. Siswa SMA diharapkan dapat menjadi ujung tombak dalam penyebaran informasi penyuluhan pada keluarga dan masyarakat, sehingga dapat menurunkan angka kejadian dan penularan IMS pada masyarakat.

\section{UCAPAN TERIMA KASIH}

Kami mengucapkan terima kasih kepada Universitas Padjadjaran yang telah membiayai penelitian ini dan Staf Departemen Ilmu Kesehatan Kulit dan Kelamin Universitas Padjadjaran sebagai pendukung utama dalam setiap tahapan kegiatan program PPM, SMA Negeri Jatinangor sebagai tempat kegiatan penyuluhan, dan semua pihak yang turut membantu kegiatan PPM ini hingga terlaksana sesuai dengan yang diharapkan.

\section{DAFTAR PUSTAKA}

Awang H, Wong LP, Jani R, Low WY. (2013). Knowledge of Sexually Transmitted Diseases and Sexual Behaviours among Malasyian Male Youths. Journal of Biosocial Science. 2 1-11. 
Badan Kependudukan dan Keluarga Berencana Nasional. Buku Suplemen Bimbingan Teknis Kesehatan Reproduksi Infeksi Menular Seksual dan HIV/ AIDS. (2013). Jakarta: Badan Kependudukan dan Keluarga Berencana Nasional: hlm. 1-22.

Centers for Disease Control and Preventation. (2018). Atlanta: Sexually Transmitted Disease Surveillance 2017: hlm. 1-168.

Gutierrez DC, Kainz K, Madeo F. (2016). Sexually Transmitted Infection: Old Foes on The Rise. Microbial Cell. 3 361-2.

Hakim L. (2011). Epidemiologi Infeksi Menular Seksual. Jakarta: Infeksi Menular Seksual, edisi ke-4: hlm 3-16.

Stovel KW, Kreager D, Moreno MA. (2008). Social Dimensions of Adolescent Sexuality. New York: Sexually Transmitted Diseases, edisi ke-4: hlm. 98-9.
Svensson L, Waern S. (2018). Knowlegde of and Attitudes to Sexually Transmitted Diseases among Thai University. Thailand: Uppsala Uviversitet: hlm 1-36.

United Nations Children's Fund. Aldolescents and youth. (2018). Melalui https://www.unicef.org/ adolescence/.

Wawan A, Dewi M. (2010). Teori dan Pengukuran Pengetahuan, Sikap, Dan Perilaku Manusia. Yogyakarta: Nuha Medika.

World Health Organization. Sexually transmitted infections (STIs). (2018). Melalui http://www. who.int/news-room/fact-sheets/detail/sexuallytransmitted-infections-(stis). 